- DOI: $10.31866 / 2410-1311.38 .2021 .247168$

УДК 008+316.347]:911.375.1(477.46-21)

\title{
КУЛЬТУРНО-ЕТНІЧНЕ СЕРЕДОВИЩЕ МІСТА УМАНЬ ЯК РЕСУРС УРБАНІСТИЧНОЇ ТРАНСФОРМАЦІЇ
}

\section{- Войцях Наталія Павлівна}

\section{- Аспірантка,}

ORCID: 0000-0002-8408-2634, e-mail: slobodskan1988@gmail.com,

Національна академія керівних кадрів культури і мистецтв,

вул. Лаврська, 9, Київ, Україна, 01015

\section{Для цитування:}

Войцях, Н.П. (2021). Культурно-етнічне середовище міста Умань як ресурс урбаністичної трансформації. Питання культурології, (38), 264-273. doi: https://doi.org/10.31866/24101311.38.2021.247168.

\section{- Анотація}

Мета статті - дослідити стратегії культурної модернізації сучасного міського середовища та проаналізувати перспективи урбаністичних трансформацій громад з багатим культурним спадком на прикладі міста Умань. Методологія дослідження полягає у комплексному використанні загальнонаукових методів: аналізу та синтезу 一 для вивчення історичного та соціокультурного процесів розвитку міського середовища в контексті урбаністичних трансформацій; опису та порівняння - для характеристики базових сценаріїв міської модернізації; кейс-стаді - для дослідження культурного середовища міста Умань. Наукова новизна пропонованого дослідження полягає в тому, що вперше такий сценарій урбаністичної трансформації, як «консервація системи» розглядається з погляду інновативності та відповідності актуальним міжнародно-правовим вимогам щодо дотримання принципів міжетнічної толерантності та ефрективного міжкультурного діалогу. Висновки. Модернізація урбаністичних середовищ має здійснюватися з урахуванням не лише географічно-ландшафтної та економіко-індустріальної специффіки міст. Важливим чинником для розробки трансформаційної стратегії є семіотично-світоглядна складова, яка унормовує, спрямовує й організовує життя локальних міських спільнот. Можна виокремити чотири базові модернізаційні стратегії ревіталізації урбаністичних просторів: «консервація системи», «демонтаж системи», «розвиток системи», «оновлення системи». Хоча перша із названих стратегій видається найконсервативнішою, бо працює з усталеними традиційними уявленнями, сакральними цінностями та звичаєвими практиками, однак має в основі новітні аксіологічно-правові настанови щодо міжетнічної толерантності, ефективного міжкультурного діалогу та поваги до культурного спадку всіх національних груп, що творили локальну історію. Яскравим зразком урбаністичної модернізації, яка могла б реалізуватися за сценарієм «збереження системи» є місто Умань.

Ключові слова: культурне середовище; урбаністична транссормація; стратегії модернізації міста; міжетнічна толерантність; міжкультурний діалог 


\section{- Вступ}

Нині спостерігається інтенсифікація урбаністичних процесів. Водночас чим більше певна країна відповідає модерним інформаційно-економічним тенденціям розвитку, тим більша частка її продуктивного й креативного населення проживає в містах. Тобто рівень урбанізації країни корелюється з рівнем її технологічного й економічного розвитку. Так, відповідно до звіту демографічного відділу ООН «Перспективи світової урбанізації» за 2020 рік, 1960 року у містах проживало 33,6 \% населення планети, $2020-56,15 \%$. Найвищі темпи міграції населення до міст зафіксовані в країнах, що розвиваються (Кувейт, Йорданія, Перу, Малайзія) та в найбільш економічно сталих державах — в Сінгапурі, Катарі, Монако, Норвегії. 3 іншого боку, у країнах, що досягли індустріального перенасичення й увійшли в інформаційну епоху, де технології забезпечують можливість продуктивної діяльності в онлайн-форматі, спостерігається протилежна тенденція: стає популярним сільський дауншифтинг. Такі тенденції панують в Австрії, Польщі, Ліхтенштейні (The World Bank, 2021). Як наслідок, міста-сателіти, села й хутори модернізуються, копіюючи за рівнем сервісу та комфорту міське середовище й витісняючи традиційний «пасторально-сільський» спосіб життя. А тому питання розробки й осмислення стратегій урбаністичних трансформацій постає особливо гостро як в теоретичному, так і в прикладному аспекті.

На початку $\mathrm{XX}$ ст. поняття урбаністичної трансфрормації трактувалося як «матеріальна» інфрраструктурна перебудова. Яскравим ії втіленням $€$ модель «індустріального урбанізму», коли місто ототожнювалося з його інфраструктурною системою: життя в ньому зосереджувалося навколо заводів, фрабрик, житлових кварталів та транспортних артерій. Відповідно до цієї стратегії у 30-ті рр. XX ст. перебудовувалися Нью-Йорк, Берлін, Мадрид.

В інформаційну епоху, коли головним економічним ресурсом стає IT-, програмне виробництво, розвиток сектору креативних індустрій, поняття «урбаністичної трансформації» набирає культур-фрілософфського сенсу, оскільки йдеться не лише про адміністрування інфраструктурної складової міського життя, але й про соціальний інжиніринг, в якому вагомість людського ресурсу, тобто соціального та культурного капіталу міста, $є$ запорукою його добробуту. А тому особливої ваги у забезпеченні міського добробуту набирають такі чинники, як локальна культурна пам'ять, ідентичність міської спільноти, рівень їі солідаризації, толерантності та взаємодовіри.

Питаннями розвитку та трансформації міст займалися такі закордонні вчені та автори урбаністичних проєктів, як Р. Мозес, Дж. Джекобс, Я. Гейл. Тансформацію культурної політики в урбаністичному просторі вивчали П. Фьоль, Д. Гарві, К. Ванер, Дж. Луід, С. Шліпченко, І. Френкель, І. Тищенко.

Найбільш виразно діяльність та функціонування релігійно-етнічних спільнот міста Умань висвітлювалась в історичному, релігійному, туристичному контекстах таких вітчизняних вчених, як І. Кривошея, В. І. Фуркало, В. С. Фуркало, С. Панченко, І. Мельник, Л. Осадча, проте спроби проаналізувати вплив релігійноетнічних спільнот міста Умань в контексті урбаністичних трансформацій не були актуальними серед науковців. Вибір даної проблематики $є$ важливим та новим для подальшого наукового дослідження. 


\section{- Мета статті}

Мета статті полягає у дослідженні стратегій культурної модернізації сучасного міського середовища та аналізі перспектив урбаністичних трансформацій громад з багатим культурним спадком на прикладі міста Умань. Наукова новизна пропонованого дослідження полягає в тому, що вперше такий сценарій урбаністичної трансформації, як «консервація системи» розглядається з погляду інновативності та відповідності актуальним міжнародно-правовим вимогам щодо дотримання принципів міжетнічної толерантності та ефективного міжкультурного діалогу.

\section{- Виклад матеріалу дослідження}

Термін «культурна модернізація» у найширшому сенсі означає «оновлення», ідентифікаційну реактуалізацію, посилення динаміки культурного життя міста чи країни, підвищення рівня побутової культури населення та розширення радіуса довіри між учасниками спільноти. Цього ефекту оновлення й інтенсифікації культурно-дозвіллєвого життя можна досягти по-різному. Так, стратегія індустріального урбанізму засновувалася на екстенсивному нарощуванні кількості дозвіллєвих локацій, житлових кварталів, прокладенні нових транспортних напрямків тощо. Культурно-дозвіллєві практики сприймалися як похідні, що залежать від фундаментальної, сталої, матеріальної інфраструктури. Вважалося, що варто створити просторово облаштовану лакуну, а людська діяльність, культурно-мистецькі практики заповнять її автоматично. Однак, як показав час, цього не сталося. Натомість виникли занедбані райони, де соціокультурна діяльність пішла на спад, бо не були враховані дозвіллєві й освітні запити місцевих жителів, а також не створено приваб для приїжджих, некорінних мешканців.

Тому на противагу індустріальній стратегії містобудування набув популярності так званий новий урбанізм, орієнтований на місцевий модернізаційний ресурс, на потреби й запити мешканців міст чи мікрорайонів. Підхід нового урбанізму орієнтований на розвиток людини, а не на механічне ускладнення міської інфрраструктури.

Залежно від соціального капіталу міста — його вікові субкультури, виробничі традиції, історичну пам'ять, наявність рекреаційних об'єктів - можна виокремити стратегії культурної модернізації міст.

А. Флієр (Флиер, 2013) у статті «Модернізація культурного середовища: варіанти цілепокладання» дає таке визначення поняття «культурне середовище» - це звичаєві, ідеологічні, естетичні особливості соціальної групи, що локалізується в автономному організованому просторі (регіоні, місті, мікрорайоні). А тому й стратегії модернізації міського культурного середовища різнитимуться залежно від того, яка зі складових розглядається як першочергова - просторова, соціальна чи семіотично-ідеологічна.

Культурно-модернізаційна стратегія має охоплювати всі три окреслені компоненти, однак саме семіотичний (ідеологічний, ціннісний, смисловий) дає змогу соціального єднання та ефективного, обґрунтованого інфраструктурного будівництва. 
А. Флієр (Флиер, 2013) виокремлює чотири базові культурно-модернізаційні стратегії ревіталізації урбаністичних просторів. Перша з них - консервація системи, здійснюється завдяки посиленню контролю над дотриманням усталених звичаїв, традицій, поведінкових габітусів. Її мета - захистити, навіть «фундаменталізувати» світоглядне ядро спільноти, створити на його основі культурну резервацію, що згодом сприйматиметься як екзотична, унікальна, туристично приваблива.

Друга стратегія - демонтаж старих культурних структур, які проявляються як практики люстрації, декомунізації, деідеологізації, деколонізації тощо.

Третя стратегія - розвиток системи шляхом контрольованого, поступового, адаптивного введення інновацій. Так, старий занедбаний індустріальний об'єкт може бути перепрофільований у мистецький хаб, воркспейс, ігрову арену зі збереженням первинної унікальної архітектурної конструкції цього об'єкта.

Четверта стратегія - оновлення системи, що супроводжується запровадженням інновацій, абсолютно не пов'язаних з колишнім культурно-дозвіллєвим профрілем міста. Це запускає ефект «культурного магніту», коли локація заповнюється новими мешканцями й акторами - представниками креативного класу.

Якщо говорити про особливості урбаністичних трансформацій українських міст, то тут не може бути єдиного підходу чи єдино вірної стратегії. Так, на часі перепрограмування смислів національної культури загалом, що обумовлюється курсом на євроінтеграцію України та необхідністю відрефлексувати радянські рудименти у нашому світосприйнятті. Однак, що поставити на місце спорожнілих постаментів, залежатиме від локальних культурних політик.

Так, для міст-мільйонників ефективними будуть спроби застосування сценарію оновлення культурного середовища. Для модернізації менших міст вже були успішно застосовані сценарії розвитку системи, наприклад у Львові, Чернігові, Івано-Франківську, Кам'янці-Подільському, Тернополі. Такі програми урбанізаційних трансформацій передбачають ретельне вивчення локальних культурних ресурсів, визначення референтної аудиторії, культурні запити якої мають бути задоволені найперше. Однак ще більш емоційно чутливим є питання урбаністичних трансформацій за сценарієм збереження системи. Їх доречно застосовувати в містах, де компактно проживають мультикультурні громади з чіткими етнічними чи релігійними ідентичностями. Наприклад, у містечку Вилкове Одеської області компактно проживає найчисельніша в Україні спільнота старообрядців-липованів поряд з православною громадою, що підтримує Українську православну церкву. Це надає як господарчого, так і естетично-побутового колориту містечку, яке має ще й ландшафтні особливості, бо розташоване в дельті Дунаю, тому вулиці тут — водні канали, а не сухопутні шляхи. Його ще називають «українською Венецією».

Сценарій «збереження системи» було б доречно реалізувати також у місті Умань Черкаської області, яке багате об'єктами матеріальної культурної спадщини попередніх епох: Національний дендрологічний парк «Софіївка» кінця XVIII ст., корпуси Головного училища садівництва початку XIX ст., костел Успіння Богородиці середини XIX ст., Свято-Успенська церква початку XX ст., могила 
Цадика Нахмана, яку щороку відвідують понад 40 тис. прочан-хасидів зі всього світу.

Поштовх до культурного розвитку міста Умань відбувся ще за часів Речі Посполитої, коли 1726 року Уманщина увійшла до володінь польського магната графра Станіслава Потоцького (Кривошея І. І. \& Кривошея Ір. І., 2019), завдяки сприянню якого сформувався архітектурний колорит міста. За стилістичний орієнтир було обрано популярний у тогочасній Європі класицизм. Місто Умань стало осередком розвитку культури пізнього класицизму і набуло нових форм в геніальних ландшафтно-архітектурних спорудах, таких як дендропарк «Софіївка» та римо-католицький костел Успіння Пресвятої Богородиці (Давидюк, 2012).

Формування урбаністичного простору міста не обмежилося лише діяльністю польської спільноти, оскільки з переходом цих земель у володіння Речі Посполитої тут почали оселятися й представники єврейського етносу. Українська медієвістка Н. Яковенко в роботі «Нарис історії України з найдавніших часів до кінця XVIII ст.» так коментує масштаби демографічної строкатості тогочасних міст на території України: «Нову виразну барву в етнічну палітру міст починають додавати євреї, чисельність яких наприкінці XVII - впродовж XVIII ст. за сприяння магнатів, зацікавлених у посередницьких та орендарських послугах, різко зросла. Так, у другій половині XVIII ст. лише на території Галичини проживало близько 30 \% євреїв усієї Речі Посполитої, де їхня загальна кількість обіймала понад 600 тис. осіб, тобто приблизно третину всього єврейського населення тогочасної Європи. За підрахунками Єжи Мотилевича, в багатьох поселеннях польсько-українського пограниччя євреї складали до половини, а деколи навіть більше міщанського загалу: у Добромилі - 70,2 \%, Перемишлі - 55,6 \%, Дрогобичі - 58,8 \%, Ряшеві - 49,8 \%, Сяноку - 36,4 \%, Ярославі - 22,3 \%. Подібні тенденції були властиві і для решти українських територій, тож власне в цей час витворюється знаний аж до Другої світової війни колоритний типаж галицького, волинського, подільського чи київського містечка як “єврейського” - $з$ обов'язковою синагогою і школою, зі звучанням на вулицях та базарах трьох - єврейської, української і польської - мов» (Яковенко, 1998, с. 332).

І. Мельник $(2018)$ у дослідженні демографічного складу населення міста Умань визначила, що наприкінці XVIII - на початку XX ст. за чисельністю населення тут переважали саме євреї. У період Другої світової війни, у зв'язку з фашисткою політикою винищення євреїв, місто Умань втратило підстави для цієї метафоричної ідентифрікації.

Але у післявоєнний період представники єврейського етносу почали повертатись до міста, де розташовані важливі для іудеїв-хасидів місця пам'яті, що фундують їх релігійно-етнічну ідентичність, зокрема йдеться про могилу Цадика Нахмана (1772-1810). Спорадично, ці місця пов'язані й з українською культурною пам'яттю. Так, 1768-1769 року Правобережна Україна була охоплена селянським повстанням - Коліївщиною, що стало реакцією на політичні та економічні утиски місцевого населення з боку польських землевласників, а пізніше й російських поміщиків на територіях Київщини. Кульмінаційною подією гайдамацького руху стало взяття Умані повстанськими військами (ряд істориків, зокрема Н. Яковенко, Л. Зашкільняк вживають термін «Уманська різанина», 
підкреслюючи масштабність та етнічне маркування жертв розправи) у червні 1768 року, яке супроводжувалося масовими вбивствами польського та єврейського населення. Сукупні людські втрати оцінюються від 12 до 20 тис. осіб. На придушення повстання були кинуті не лише місцеві польські гарнізони, а також російські, що дислокувалися на Лівобережжі, оскільки повстанський рух перекинувся й на Наддніпрянщину.

В пам'ять про тогочасні жертви серед єврейського населення Умані рабі Нахман заповів своїм послідовникам поховати його в цьому місті поряд з могилами мучеників-одновірців: «I незадовго до смерті у 1810 році, зібравши учнівхасидів у ніч на Рош-га-Шана, заповів всім своїм наступникам приходити до нього щороку на могилу саме на це свято» (Головцов, 2015, с. 64). Варто наголосити, що представник спільноти хасидів рабі Нахмана першим започаткував таку культурну практику, як релігійне паломництво до міста Умань ще у XIX ст. Нині ж за кількісними показниками іноземних туристів, а саме хасидів, місто складає конкуренцію лише Львову та Києву. С. Панченко (2018) у своєму дослідженні «Культуротворчий потенціал релігійного туризму: становлення українського досвіду» зазначає, що важливий вплив на розвиток української культури має туристичний потенціал, зокрема релігійне паломництво хасидів. Йдеться не лише про економічні переваги від розвитку туристичної інфраструктури міста: сервісів із забезпечення харчових, житлових, розважальних послуг, але й про роботу з культурними смислами, цінностями для фактологічного й наративного збагачення національного історичного дискурсу та привернення уваги до питань міжкультурної та міжрелігійної толерантності в Україні.

Головною перевагою урбаністично-трансформаційного сценарію «недоторканності системи» $€$ те, що він забезпечує однаково поважне ставлення до всіх традицій та історичних надбань, пов'язаних з конкретною урбаністичною локацією. Так, в Умані $є$ можливості рівноправно пошановувати пам'ять та здобутки як представників єврейської, так і польської та української етнічних спільнот. На території міста розташована як могила Цадики Нахмана, так і єдиний в Україні меморіальний монумент провідникам гайдамацького руху — Іванові Гонті та Максиму Залізняку.

Хасидська громада є важливим агентом трансформації візуального середовища Умані. Так, проходячи вулицями міста можна доволі часто зустріти інформаційні та рекламні тексти, написані українською мовою та продубльовані івритом, зокрема це стосується вулиці Пушкіна, прилеглої до Історико-культурного центру брацлавських хасидів (місця, де знаходиться могила Цадика Нахмана). Тут майже всі назви готелів, ресторанів, кафе, магазинів, рекламних щитів і навіть візитівок таксистів написані на івриті.

Міжкультурна комунікація здійснюється також як фандрейзингова взаємодія локальних єврейської та української спільнот. Так, 2018 року представник хасидської спільноти Хаїм Хазін здійснив фрінансову підтримку концертної діяльності на відзначення двадцятої річниці вокального ансамблю «Гонта», що фрункціонує на базі Уманського державного педагогічного університету імені Павла Тичини.

При внесенні до стратегії розвитку міста окремих положень, спрямованих на посилення мультикультурності та міжрелігійної толерантності, Умань могла б 
стати ілюстративним кейсом, що засвідчував би високу культуру українців зі збереження історичної пам'яті.

\section{- Висновки}

Модернізація урбаністичних середовищ має здійснюватися з урахуванням не лише географічно-ландшафтної та економіко-індустріальної специфіки міст. Важливим чинником для розробки трансформаційної стратегії $є$ семіотичносвітоглядна складова, яка унормовує, спрямовує й організовує життя локальних міських спільнот. Можна виокремити чотири базові культурно-модернізаційні стратегії ревіталізації урбаністичних просторів: «консервація системи», «демонтаж системи», «розвиток системи», «оновлення системи». Хоча перша із названих стратегій видається найтрадиційнішою, бо працює з усталеними уявленнями, сакральними цінностями та звичаєвими практиками, однак має в основі новітні аксіологічно-правові настанови щодо міжетнічної толерантності, ефективного міжкультурного діалогу та поваги до культурного спадку всіх національних груп, що творили локальну історію. Яскравим зразком урбаністичної модернізації, яка могла б реалізуватися за сценарієм «збереження системи»є місто Умань.

\section{- Список використаних джерел}

Головцов, А. Л. (2015). Дом над парком (2-е изд.). Альфа Реклама.

Давидюк, В. М. (2012). Історія уманських вулиць: вулиця Коломенська, вулиця Леніна та вулиця Піотковського (Вип. 2). Візаві.

Кривошея, І. І., \& Кривошея, Ір. І. (2019). Місто на кордоні: Умань - урбанізований простір міжетнічного компромісу (взаємодії) чи конфрлікту? (1616-2018рр.). Русин, 55, 84-112.

Мельник, І. В. (2018). Єврейське населення Уманщини наприкінці XVIII - на початку $X X \mathrm{~cm}$. [Дисертація кандидата історичних наук, Уманський державний педагогічний університет імені Павла Тичини.]

Панченко, С. А. (2018). Культуротворчий потенціал релігійного туризму: становлення українського досвіду [Дисертація кандидата культурології, Національна академія керівних кадрів культури і мистецтв].

Флиер, А. Я. (2013). Модернизация культурной среды: варианты целеполагания. Гуманитарные науки: теория и методология, 3, 65-73. http://www.zpujournal.ru/zpu/contents/2013/3/Flier_Cultural-Environment\%E2\%80\%99sModernization/10_2013_3.pdf

Яковенко, Н. (1998). Нарис історії України з найдавніших часів до кінця XVIII століття. Генеза.

The World Bank. (2021). Urban population (\% of total population). United Nations Population Division. World Urbanization Prospects: 2018 Revision. https://data.worldbank.org/ indicator/SP.URB.TOTL.IN.ZS

\section{- References}

Davydiuk, V. M. (2012). Istoriia umanskykh vulyts: vulytsia Kolomenska, vulytsia Lenina ta vulytsia Piotkovskoho [History of Uman Streets: Kolomenska Street, Lenina Street and Piotkovskoho Street] (Iss. 2). Vizavi [in Ukrainian]. 
Flier, A. Ya. (2013). Modernizatsiya kul'turnoi sredy: varianty tselepolaganiya. [Cultural Environment's Modernisation: the Variants of Goal Setting]. Gumanitarnye Nauki: Teoriya i Metodologiya, 3, 65-73. http://www.zpu-journal.ru/zpu/contents/2013/3/ Flier_Cultural-Environment\%E2\%80\%99s-Modernization/10_2013_3.pdf [in Russian]. Holovtsov, A. L. (2015). Dom nad parkom [House Over the Park] (2 ${ }^{\text {nd }}$ ed.) Alfa Reklama [in Ukrainian].

Krivosheia, I. I., \& Krivosheia, Ir. I. (2019). Misto na kordoni: Uman — urbanizovanyi prostir mizhetnichnoho kompromisu (vzaiemodii) chy konfliktu? (1616-2018 rr.) [City on the Border: Uman - an Urbanised Space of Inter-ethnic Compromise (Interaction) or Conflict? (1616-2018)]. Rusyn, 55, 84-112 [in Ukrainian].

Melnyk, I. V. (2018). Yevreiske naselennia Umanshchyny naprykintsi XVIII - na pochatku $X X$ st. [The Jewish Population of Uman Region in the Late Eighteenth - Early Twentieth Century] [PhD Dissertation, Pavlo Tychyna Uman State Pedagogical University] [in Ukrainian].

Panchenko, S. A. (2018). Kulturotvorchyi potentsial relihiinoho turyzmu: stanovlennia ukrainskoho dosvidu [Cultural Potential of Religious Tourism: the Formation of the Ukrainian Experience] [PhD Dissertation, National Academy of Culture and Arts Managemen] [in Ukrainian].

The World Bank. (2021). Urban population (\% of total population). United Nations Population Division. World Urbanization Prospects: 2018 Revision. https://data.worldbank.org/ indicator/SP.URB.TOTL.IN.ZS [in English].

Yakovenko, N. (1998). Narys istorii Ukrainy z naidavnishykh chasiv do kintsia XVIII stolittia [Essay on the History of Ukraine From Ancient Times to the End of the $18^{\text {th }}$ Century]. Genesis [in Ukrainian].

\title{
- CULTURAL AND ETHNIC ENVIRONMENT OF THE CITY OF UMAN AS A RESOURCE FOR URBAN TRANSFORMATION
}

\author{
- Nataliia Voitsiakh \\ PhD Student, \\ ORCID: 0000-0002-8408-2634, e-mail: slobodskan1988@gmail.com, \\ National Academy of Culture and Arts Management, \\ Kyiv, Ukraine
}

\section{Abstract}

The purpose of the article is to study the strategies for cultural modernisation of the modern urban environment and analyse the prospects for urban transformations of communities with a rich cultural heritage on the example of the city of Uman. The research methodology consists in the integrated use of general scientific methods: the methods of analysis and synthesis were applied to study the historical and sociocultural processes of urban environment development in the context of urban transformations; the methods of description and comparison were used to characterise the basic scenarios of urban modernisation; case studies are used to examine the cultural environment of the city of Uman. The scientific novelty of the research lies in the 
fact that for the first time such a scenario of urban transformation as "inviolability of the system" is considered from the point of view of innovation and compliance with current international legal requirements for observing the principles of interethnic tolerance and effective intercultural dialogue. Conclusions. Modernisation of urban environments should take into account not only the geographical and landscape, economic and industrial characteristics of the city. An important factor for developing a transformation strategy is the semiotic-ideological component, which regulates, directs and organises the life of local communities. There are four basic modernisation strategies for the revitalisation of urban spaces: "system inviolability", "system destruction", "system development", "system renewal". Although the first of these strategies seems to be the most conservative, since it works with established traditional ideas, sacred values, and customary practices, it is based on the latest axiological and legal guidelines for interethnic tolerance, effective intercultural dialogue, and respect for the cultural heritage of all national groups that created local history. The city of Uman is a striking example of urban modernisation, which could be implemented under the scenario of "system inviolability".

Keywords: cultural environment; urban transformation; urban modernisation strategies; interethnic tolerance; intercultural dialogue

\section{КУЛЬТУРНО-ЭТНИЧЕСКАЯ СРЕДА ГОРОДА УМАНЬ КАК РЕСУРС УРБАНИСТИЧЕСКОЙ ТРАНСФОРМАЦИИ}

\section{- Войцях Наталия Павловна}

\section{- Аспирантка,}

ORCID: 0000-0002-8408-2634, e-mail: slobodskan1988@gmail.com,

Национальная академия руководящих кадров культуры и искусств,

Киев, Украина

\section{- Аннотация}

Цель статьи - исследовать стратегии культурной модернизации современной городской среды и проанализировать перспективы урбанистических трансформаций сообществ с богатым культурным наследием на примере города Умань. Методология исследования заключается в комплексном использовании общенаучных методов: анализа и синтеза - для изучения исторического и социокультурного фракторов развития городской среды в контексте урбанистических трансформаций; описания и сравнения для характеристики базовых сценариев городской модернизации; кейс-стади - для исследования культурной среды города Умань. Научная новизна предлагаемого исследования заключается в том, что впервые такой сценарий урбанистической трансформации, как «консервация системы», рассматривается с точки зрения инновативности и соответствия актуальным международно-правовым требованиям к соблюдению принципов межэтнической толерантности и эффективного межкультурного диалога. Выводы. Модернизация урбанистического пространства должна происходить с учетом не только географически-ландшафтной и экономико-индустриальной специфики города. Важным фрактором для разработки трансформационной стратегии является 
семиотически-мировоззренческая составляющая, которая нормирует, направляет и организовывает жизнь локальных городских сообществ. Можно выделить четыре основные модернизационные стратегии ревитализации урбанистических пространств: «консервация системы», «демонтаж системы», «развитие системы», «обновление системы». Хотя первая из названных стратегий кажется наиболее консервативной, поскольку работает с устоявшимися традиционными представлениями, сакральными ценностями и обычаями, однако имеет в основе новейшие аксиологически-правовые установки касательно межэтнической толерантности, эфффективного межкультурного диалога и уважения к культурному наследию всех национальных групп, причастных к локальной истории. Ярким примером урбанистической модернизации, которая могла бы быть реализованной по сценарию «сохранения системы», является город Умань.

Ключевые слова: культурная среда; урбанистическая трансформация; стратегии модернизации города; межэтническая толерантность; межкультурный диалог 